\title{
The Measurement of Consumer Satisfaction with Selected Elements of the Total Retail Experience: An Exploratory Study of Fast Food and Supermarket Retailers
}

\section{N S Terblanché}

Department of Business Management, University of Stellenbosch

\section{Boshoff}

Department of Business Management, University of Port Elizabeth

\section{ABSTRACT}

Although attempts have been made to identify some of the dimensions of retail shopping experience, these have been largely fragmented and uncoordinated. No attempt has yet been made to combine the efforts of many retailing students into a comprehensive model that accurately describes the total retailing experience. Also, very little is known about the relationship between the individual dimensions of retail shopping and customer satisfaction. This study attempts to reduce this gap in South African retailing literature by, first modelling the total retailing experience and, then, assessing the influence of selected individual retailing dimensions on customer satisfaction. It also investigates whether the impact of these dimensions of the retailing experience differs between fast food restaurants and supermarket retailers. The empirical results suggest a fairly consistent pattern of relationships between fast food restaurants and supermarkets.

JEL L 81

\section{INTRODUCTION}

The retail environment worldwide is in a constant state of adjustment and adaptation. Although competition, emanating from new entrants and formats as well as foreign sources, contributes to this constant flux, consumers also exert a major influence on this state of affairs. Present-day consumers not only have more choices than ever before, they also have more information at their disposal than ever before. In addition, increasing pressure of time may decrease the propensity to remain loyal to a retailer. Consumers often also assume that various rights and choices are owed to them (Schriver, 1997). Against this 
background, many retailers attempt to differentiate themselves by implementing loyalty schemes to attract and retain customers.

Another avenue open to retailers to differentiate themselves, is to deliver exceptional service quality as part of their retailing strategy (Berry, 1986; Hummel \& Savitt, 1988; Reichheld \& Sasser, 1990). The marketing literature of the past decade contains many pages devoted to service quality, especially to SERVQUAL, the instrument developed to measure service quality (Parasuraman, Zeithaml \& Berry, 1988). Most of the studies using or assessing the SERVQUAL instrument were conducted in fairly "pure" services settings like banking, credit card services and securities brokerage. Because a retail store experience involves activities such as browsing, price comparisons, search for merchandise, evaluating product variety and quality, and interaction with store personnel, the SERVQUAL instrument in its original form is not suitable to capture the unique blend of merchandise and service that makes up a retailing experience. Recently Dabholkar, Thorpe and Rentz (1996) proposed an instrument based on SERVQUAL, which they suggest measures service quality in a retailing environment. Apart from the common dimensions that are likely to be shared by pure service environments and retail environments, this instrument also captures additional dimensions of retail service quality unique to the retail environment. The development of the instrument is justified on the grounds that current measures of service quality do not adequately capture customers' perceptions of service quality for retail stores (i.e. stores that offer a mix of goods and services). Support for this view, inter alia, emerged from the findings of Finn and Lamb (1991) that tested SERVQUAL in four different types of retail store and did not find a good fit to the five-factor structure. They therefore concluded that SERVQUAL, without modification, could not be used as a valid measure of service quality in retailing.

Yet another alternative available to retailers, with which they can differentiate themselves, is to provide a positive total retail experience (TRE) for their clients. Our contention is that in retailing where a mix of goods and services is offered, the focus should rather be on the management of the controllable elements of the total retail experience, as opposed to a perspective restricted to the management of service quality only. When considered in this way, service quality is only a component of the consumer's total retailing experience.

THE TOTAL RETAIL EXPERIENCE: A BRIEF OVERVIEW OF THE LITERATURE

Berman and Evans (1998: 19) define total retail experience as all the elements that encourage or inhibit consumers in their contact with the retailer. The total 
retail experience is influenced by two groups of components. The first group consists of the non-controllable components. These include aspects such as adequacy of street parking, timing of deliveries from suppliers and taxes, all of which are not controllable by the retailer. The controllable components, in turn, consist of a variety of elements that the retailer can indeed control, like the number of salespeople on the floor, variety of brands carried and stock on hand. In this study the emphasis is on the controllable elements of the total retail experience.

The retail literature suggests that the dimensions of the controllable components may be grouped under seven dimensions. A brief description of the controllable components of the total retail experience follows below.

\subsection{Personal interaction as a dimension of the total retail experience}

Loyal customers are the backbone of any retailer's business (Schriver, 1997: 2021; Reicheld, 1993: 68). It is thus in the interest of a retailer to enter into and maintain long-term relationships with customers. The personal interaction element of the total retail experience offers numerous opportunities for creating and fostering long-term bonds with customers. Some of the typical activities that are suitable for personal interaction are selling and finalising transactions, providing information, reducing perceived risk, providing accompanying services and handling complaints (Davidson, Sweeney \& Stampfl, 1988: 143; Speer, 1996: 13-14).

\subsection{Tangibles as a dimension of the total retail experience}

The tangibles that are elements of the total retail experience, are also components of the overall image that a retailer wishes to project to consumers. Tangibles include such aspects as physical facilities, transaction documentation, and appearance of personnel and materials that enhance the service delivery and communication of a retailer (Parasuraman, Berry \& Zeithaml, 1991: 41; Dabholkar, Thorpe \& Rentz, 1996: 6-7). The tangible physical environment and atmosphere can assume a variety of roles in the marketing and management of a retailer (Bitner, 1992: 67). Insights and evidence from the environmental psychology literature support the notion that physical surroundings can influence the attitudes as well as the behaviour of consumers in a retail shop (Donovan \& Rossiter, 1982; Darden, Erdem \& Darden, 1983; Ridgway, Dawson \& Bloch, 1990). Tangible store attributes can also be seen as the "means" by which a consumer is able to achieve a desired "end", like a satisfying total retail experience (Kerin, Jain \&Howard, 1992: 381). 


\subsection{Perceived product quality as a dimension of the total retail experience}

Perceived product quality has been identified as a determinant of a consumer's perceived value of a product (Dodds, Monroe \& Grewal, 1991; Kerin, Jain \& Howard, 1992: 382) and will therefore have an influence on the TRE of a consumer. Various researchers have also reported on the importance of the quality of products (merchandise) in consumers' perception and evaluation of retail shops (Dabholkar, Thorpe \& Rentz, 1994: 4). In a more recent study Sirohi, Mclaughlin and Wittink (1998: 240) operationalised product quality for a supermarket with fifteen indicators. For some products their quality level is of great importance to the consumer, and some retailers position themselves mainly on this basis. Retailers selling high quality, high priced, well-known luxury brands are examples of this.

\subsection{Product variety and assortment as a dimension of the total retail experience}

Product variety and assortment are components of the conventional retail marketing mix (Hasty \& Reardon, 1997: 11). Products are probably the most complex expectation customers have of retail shops, because they expect to find a variety or a selection of different kinds of products consistent with personal shopping intentions and preferences (Davidson, Sweeney \& Stampfl, 1988: 141). The range of food and other product lines that supermarkets, for instance, offer, illustrates the complexity of the product variety decision. Consumers not only expect to find a variety of product lines, but also an assortment of different colours, brands, styles, models and sizes for each line. Product variety and the depth of assortment will to a large extent be influenced by the image the retailer wishes to project. For example, a supermarket's product variety and assortment, is associated with the customer services and facilities of the supermarket (Bishop, 1984; Doyle, 1984). Kerin, Jain and Howard (1992: 385) also reported that previous research and focus groups found overall variety and assortment to be indicators of the shopping experience. The importance of assortment and variety in retailing is also confirmed by the fact that one of the items in the Index of Consumer Sentiment Toward Marketing deals with the adequacy of the selection of products offered by retail shops (Gaski \& Etzel, 1986: 79).

\subsection{Store environment as a dimension of the total retail experience}

Store environment includes all the elements that contribute towards a pleasant shopping atmosphere. These elements are shop layout, aisles that make it easy to shop, store cleanliness, well-spaced product displays and attractive décor. The retail literature suggests that customers value the convenience that physical aspects, such as store layout, contribute to shopping (Gutman \& Alden, 1985; 
Hummel \& Savitt, 1988; Mazursky \& Jacoby, 1985; Oliver, 1981). Dabholkar et $a l$. also found empirical support for the contribution of shop layout to shopping convenience (1996: 7). Dabholkar et al. (1996: 6) again treated store appearance and store convenience as two sub-dimensions of the physical aspects in their study. The marketing literature supports the notion that consumers use the physical environment to form attributions about service failures, and base purchase decisions on inferences they make from various elements of the physical environment (Bitner, 1990; Ward, Barnes \& Bitner, 1992; Bloom \& Reve, 1990; Zeithaml, 1988).

\subsection{Product prices as a dimension of the total retail experience}

Gaski and Etzel (1986) used price as a component in their Index of Consumer Sentiment Toward Marketing. This stresses the importance of prices in consumer decision-making. In the absence of other cues, consumers tend to use price as an indicator of product quality (Davidson, Sweeney \& Stampfl, 1988: 143). Price is a generally controllable extrinsic cue of a product that has an influence on the way shoppers perceive product quality (Sirohi et al., 1998: 226). Price as an extrinsic cue is, for example, most relevant in a supermarket, as consumers do not regard the time and effort spent in evaluating intrinsic cues as significant (Sirohi et al., 1998: 227). Price is therefore one of the extrinsic cues that has received a great deal of attention in research (Dodds, Monroe \& Grewal, 1991; Mazursky \& Jacoby, 1985; Rao \& Monroe, 1989). Kerin, Jain \& Howard (1991: 383) suggest that because of the variety of extrinsic cues available in a supermarket (e.g. cleanliness, assortment and variety), price and quality perceptions could co-vary and that consumers "get what they pay for".

\subsection{Policy as a dimension of the total retail experience}

Policy as a dimension of the total retail experience captures those elements that are influenced by a shop's responsiveness to the customer's needs (Dabholkar et al., 1996: 7). Typical policy elements would apply to areas of shop operations such as the return or exchange of purchases, shopping hours, payment options available and a system or process to deal with customer enquiries and/or complaints (Westbrook, 1981; Mazursky \& Jacoby, 1985; Dickson \& Maclachlin, 1990; Dickson \& Albaum, 1977). The way in which a retailer responds to a service failure is essential for the maintenance of customer loyalty (Berry \& Parasuraman, 1991) as well as a positive TRE because a service failure and the subsequent recovery efforts create strong memories for customers (Zeithaml \& Bitner, 1996: 126). 


\section{OBJECTIVES OF THE STUDY}

The main objective of this study was to compare an "overall model" based on data collected from 2063 customers of four retail sectors, namely clothing, hardware, supermarkets and fast food, with two identical models based on only the data from the fast food sub-sample (635 cases) and the supermarket subsample ( 665 cases). This comparison tried to assess the stability of the model. It was believed that if the three models returned similar fit indices in relatively diverse retail environments such as supermarkets and fast food, this would represent strong evidence of generalisability. The following propositions were considered:

PROPOSITION 1: The model fit indices of the total sample, the fast food sample and the supermarket sample will not differ substantially.

A second objective was to assess whether the three dimensions of the total retail experience modelled in this study as predictors of customer satisfaction would impact on customer satisfaction to a similar extent. The following proposition was considered:

PROPOSITION 2: The path coefficients measuring the influence of the three dimensions of the total retailing experience (personal interaction, physical cues and product variety and assortment) on customer satisfaction, will be the same for the total sample, the fast food sample and the supermarket sample.

The theoretical model that was tested empirically is illustrated in Figure 1. 


\section{Figure 1 The theoretical model}

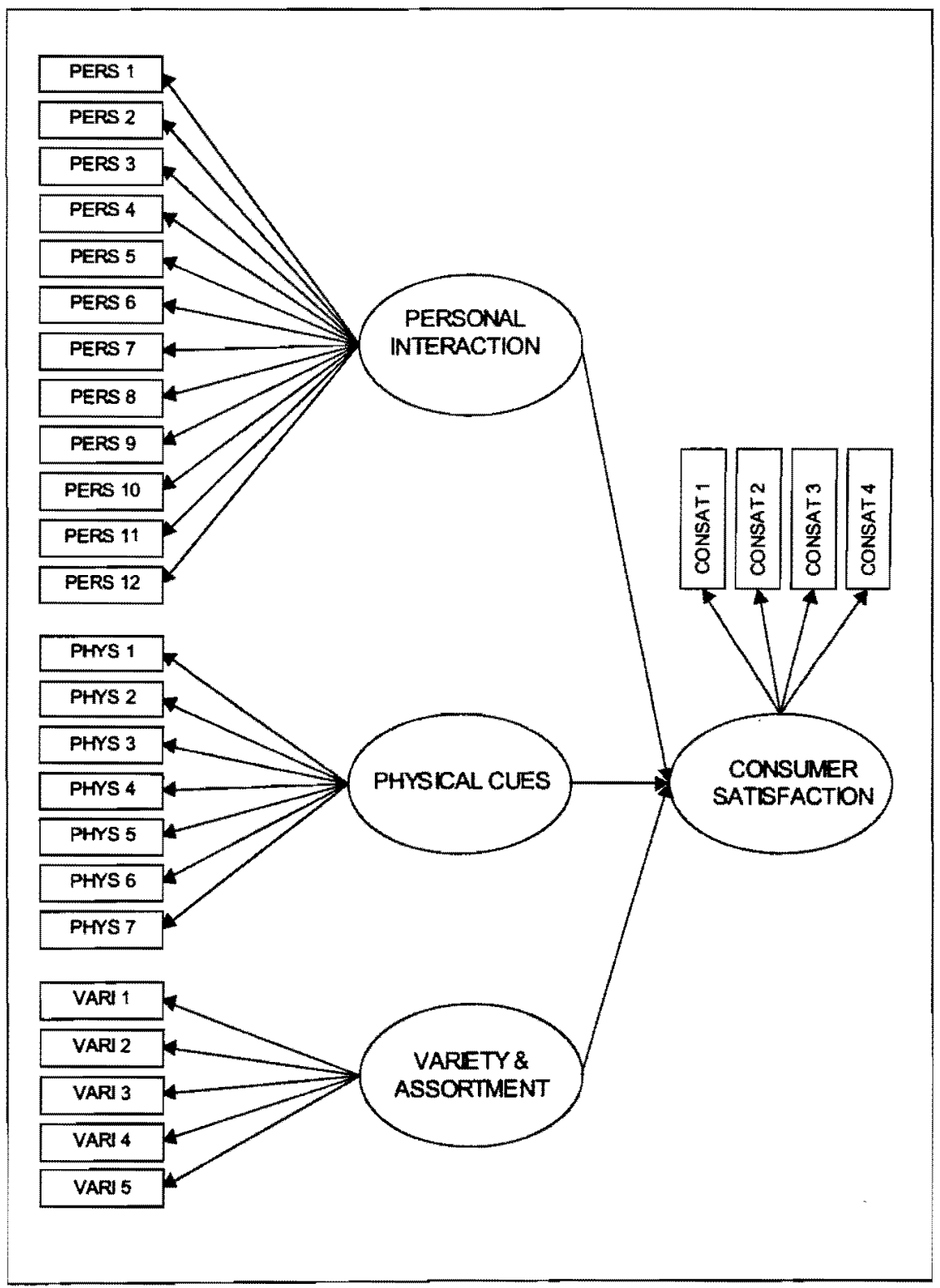




\section{METHOD}

\subsection{Generation of the questionnaire items}

Despite the criticism levelled against SERVQUAL (Buttle, 1995), the items used for the measurement of the various dimensions of service quality, are also regarded as suitable to measure some of the controllable elements of the total retail experience. For example, physical facilities, equipment, materials, business hours and various aspects of staff behaviour are covered by the items of SERVQUAL. The items of four of the SERVQUAL dimensions, namely responsiveness, reliability, empathy and assurance, were used in this study to measure the personal interaction component of the total retail experience (Kerin, Jain \& Howard, 1992; Zeithaml, 1988; Dabholkar, Thorpe \& Rentz, 1996; Sirohi, Mclaughlin \& Wittink, 1998; Baker, Grewal \& Parasuraman, 1994; Ghosh \& McLafferty, 1987). SERVQUAL has proved to be an adequate measure of the reliability, responsiveness, empathy and assurance dimensions of service delivery. All of these dimensions are of prime importance in the interaction between customers and shop personnel (Parasuraman, Berry \& Zeithaml, 1991: 41).

The product variety/assortment and product quality dimensions were measured with self-generated items and published scales. The three product quality items suggested by Finn and Kayandé (1997) were supplemented with two selfgenerated items. Product variety and assortment were measured with a five-item instrument. The tangible components involved in service delivery were measured with the original four items of SERVQUAL. All items were linked to a 7-point Likert-type scale.

Satisfaction was measured by means of the following four items :

- Will you continue to buy from XXX in the future ?

- How do you rate the overall service of XXX?

- How often have you complained about service at XXX ?

- How often have you returned unsatisfactory products to XXX ?

\subsection{Sample and data collection}

The procedure followed in this study was a combination of judgement, convenience and random sampling. Four retail industries were selected on a judgmental basis, namely fast food, clothing, supermarkets, and hardware stores. These industries were selected because they offer a combination of both service and physical products, and their market offer cannot be described as a "pure" service, independent of any other service component. Two organisations in each industry were then selected on a convenience basis and invited to participate in 
the study. Individual respondents (customers) to be interviewed were selected on a simple random basis. Personal interviews, using a structured questionnaire, were conducted with customers of firms in these four industries, on the retailer's premises following a shopping visit. The interviews were conducted over a period of a month to include all the various types of clients in terms of time frequenting the retailers as well as cash and account customers. For example, it was necessary to conduct interviews at night-time with clients from the fast food retailers. A total of 2063 questionnaires were completed.

\subsection{Scale purification}

The first step in the data analysis process was to assess how many dimensions the data contained. For this purpose, a Maximum Likelihood Exploratory Factor Analysis was done, specifying a Direct Quartimin oblique rotation (Jennrich \& Sampson 1966) of the original factor matrix. Several different factor solutions were considered. The most interpretable factor structure (factor loading exceeding 0.04 and no crossloadings) to emerge, was a 3 -factor solution. All the factors in the 3-factor solution had Eigen values above 1.00 and a sufficient number of items loading on them to a significant (0.40) extent (Hair, Anderson, Tatham \& Black, 1998). Table 1 shows the sorted rotated factor loadings matrix. The three factors that emerged were named personal interaction (measured by 3 assurance, 4 empathy, 2 reliability and 3 responsiveness items of SERVQUAL), physical cues (measured by 1 reliability and 2 tangibles items of SERVQUAL and 4 quality items) and variety (represented by 5 variety items). The items that did not load to a significant extent on a separate factor were excluded from subsequent statistical analysis. The remaining 24 items were then subjected to a reliability analysis to assess the internal consistency of the instrument. All three factors, as well as the overall instrument returned Cronbach alpha coefficients above the 0.7 level suggested by Peterson (1994). The reliability results are summarised in Table 2.

The theoretical model depicted in Figure 2 was then subjected to empirical assessment. The structural equation modelling capabilities of the computer programme RAMONA (Browne \& Mels, 1992) were used for this purpose. 
Table 1 Sorted Rotated Factor Loadings

\begin{tabular}{|l|c|c|c|}
\cline { 2 - 4 } \multicolumn{1}{c|}{} & $\begin{array}{c}\text { Factor 1 } \\
\text { personal } \\
\text { interaction }\end{array}$ & $\begin{array}{c}\text { Factor 2 } \\
\text { physical } \\
\text { cues }\end{array}$ & $\begin{array}{c}\text { Factor 3 } \\
\text { product variety } \\
\text { and assortment }\end{array}$ \\
\hline PERS 1 & $\mathbf{0 . 8 5 9}$ & -0.024 & -0.047 \\
\hline PERS 2 & $\mathbf{0 . 8 2 6}$ & -0.080 & 0.022 \\
\hline PERS 3 & $\mathbf{0 . 7 9 8}$ & -0.022 & -0.032 \\
\hline PERS 4 & $\mathbf{0 . 7 5 8}$ & $\mathbf{0 . 0 5 0}$ & -0.067 \\
\hline PERS 5 & $\mathbf{0 . 7 5 1}$ & -0.048 & 0.038 \\
\hline PERS 6 & $\mathbf{0 . 7 4 0}$ & -0.006 & 0.041 \\
\hline PERS 7 & $\mathbf{0 . 7 3 1}$ & 0.035 & -0.016 \\
\hline PERS 8 & $\mathbf{0 . 6 6 2}$ & 0.117 & -0.044 \\
\hline PERS 9 & $\mathbf{0 . 6 2 6}$ & -0.024 & 0.227 \\
\hline PERS 10 & $\mathbf{0 . 6 1 4}$ & 0.110 & 0.080 \\
\hline PERS 11 & $\mathbf{0 . 5 7 8}$ & 0.082 & 0.170 \\
\hline PERS 12 & $\mathbf{0 . 4 5 8}$ & 0.281 & 0.013 \\
\hline PHYS 1 & -0.087 & $\mathbf{0 . 8 2 6}$ & 0.035 \\
\hline PHYS 2 & -0.058 & $\mathbf{0 . 8 1 0}$ & 0.090 \\
\hline PHYS 3 & 0.024 & $\mathbf{0 . 7 7 0}$ & 0.039 \\
\hline PHYS 4 & 0.157 & $\mathbf{0 . 5 3 9}$ & -0.014 \\
\hline PHYS 5 & 0.075 & $\mathbf{0 . 4 4 8}$ & 0.155 \\
\hline PHYS 6 & 0.272 & $\mathbf{0 . 4 4 4}$ & -0.042 \\
\hline PHYS 7 & $\mathbf{0 . 1 4 8}$ & $\mathbf{0 . 4 0 0}$ & 0.117 \\
\hline VARI 1 & -0.007 & 0.086 & $\mathbf{0 . 8 0 5}$ \\
\hline VARI 2 & 0.042 & -0.113 & $\mathbf{0 . 7 9 3}$ \\
\hline VARI 3 & -0.046 & 0.099 & $\mathbf{0 . 6 6 0}$ \\
\hline VARI 4 & 0.038 & 0.118 & $\mathbf{0 . 6 5 9}$ \\
\hline VARI 5 & 0.146 & 0.166 & $\mathbf{0 . 4 3 4}$ \\
\hline EIGEN & 6.196 & 2.940 & 2.486 \\
\hline & & & \\
\hline
\end{tabular}

Table 2 Reliability Analysis Results: Total sample

\begin{tabular}{|l|l|}
\hline \multicolumn{1}{|c|}{ Dimensions } & $\propto$ \\
\hline Personal interaction & .937 \\
Physical cues & .863 \\
Variety & .857 \\
Consumer satisfaction & .725 \\
Overall & .948 \\
\hline
\end{tabular}


Table 3 Fit Indices

\begin{tabular}{|l|c|c|c|}
\hline & Total Sample & Fast Food & Supermarket \\
\hline Chi-square (df) & $2243.49(249)$ & $1473.8(344)$ & $1240.5(344)$ \\
\hline RMSEA & 0.062 & 0.072 & 0.063 \\
\hline GFI & 0.900 & 0.846 & 0.882 \\
\hline AGFI & 0.880 & 0.818 & 0.861 \\
\hline ECVI & 1.566 & 2.520 & 2.056 \\
\hline Parsimonious Fit Indices & & & \\
\hline PNFI & 0.826 & 0.761 & 0.818 \\
\hline PGFI & 0.816 & 0.770 & 0.803 \\
\hline NFI & 0.908 & 0.837 & 0.899 \\
\hline
\end{tabular}

\section{FINDINGS}

When comparing different models, the parsimonious fit indices produced by most SEM programmes ought to be used (Hair Anderson Tatham \& Black, 1998: 658). Hair et al. (1998) suggest that when comparing two models, the Parsimonious Normed Fit Index (PNFI) is particularly useful. Differences between 0.06 to 0.09 are regarded as "indicative of substantial model differences". When comparing the PNFI of the fast food sample (model) with the supermarket model the difference is 0.057 , and when comparing the total model with the supermarket model the difference is only 0.008 - both less than the lower bound of the range for substantial model difference proposed by Hair et al. (1998). When comparing the total model with the fast food model, the difference is 0.065 - just inside the range proposed by Hair et al. The total model is thus not quite as good a predictor of customer satisfaction for a fast food restaurant as it is for a supermarket. It appears as if the model fares slightly better in retail environments where physical products are dominant in the market offering as opposed to services (the fast food industry). However, given the relatively small PNFI differences, Proposition 1 is accepted.

The empirical results of the three empirical models (the total sample, and the fast food and supermarket samples) are depicted in Figures 2,3 and 4. In the total sample (Figure 2) personal interaction $(0.585 ; \mathrm{p}<0.01)$ and physical cues $(0.312 ; p<0.01)$ are strong predictors of consumer satisfaction, while the variety and assortment dimension does not influence consumer satisfaction. 
Figure $2^{\text {1) }}$ Empirical Results: Determinants of Satisfaction with Selected Controllable Elements of the Total Retail Experience

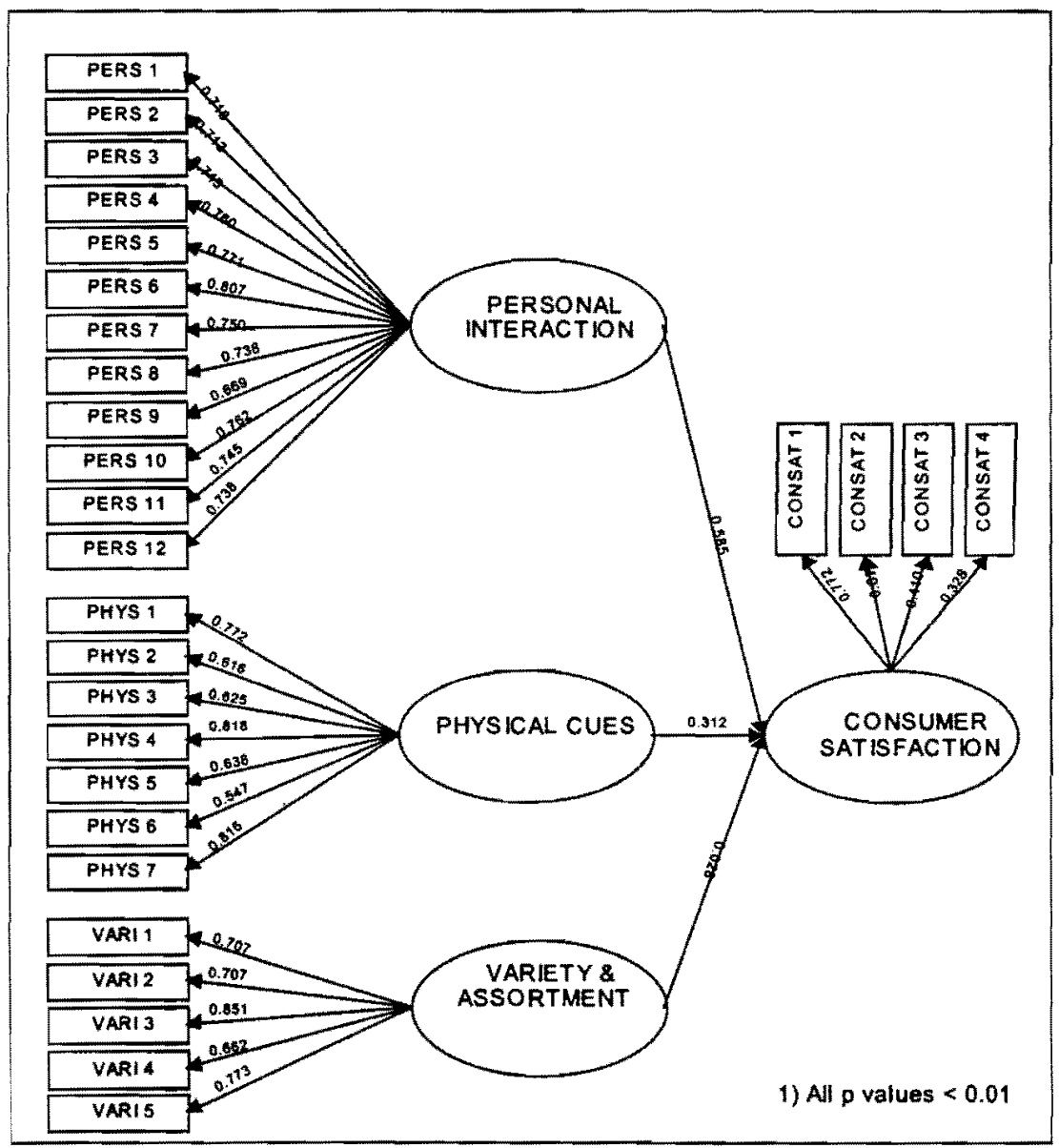




\section{Figure 3 Tre - Fast Foods}

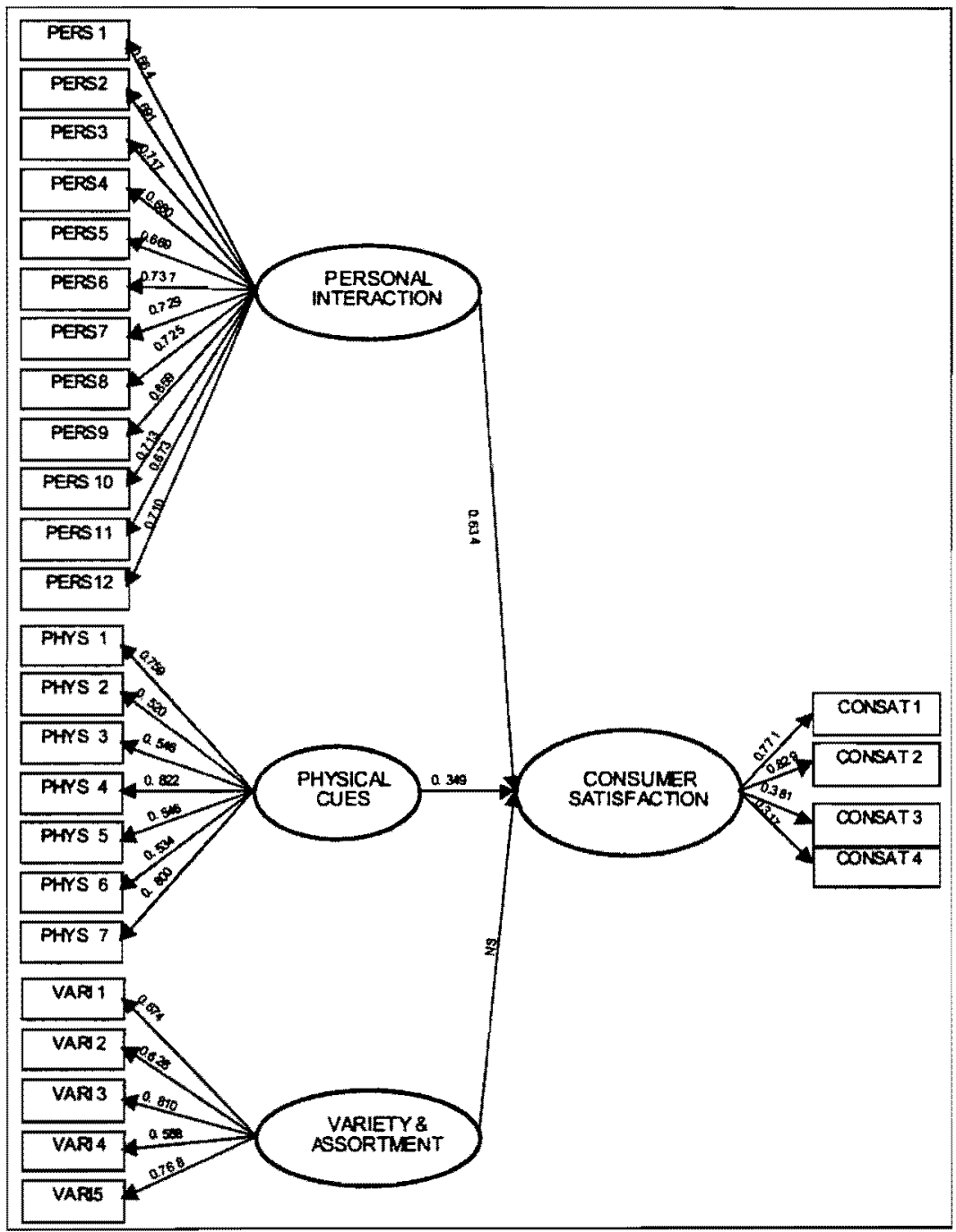




\section{Figure 4 Tre-Supermarkets}

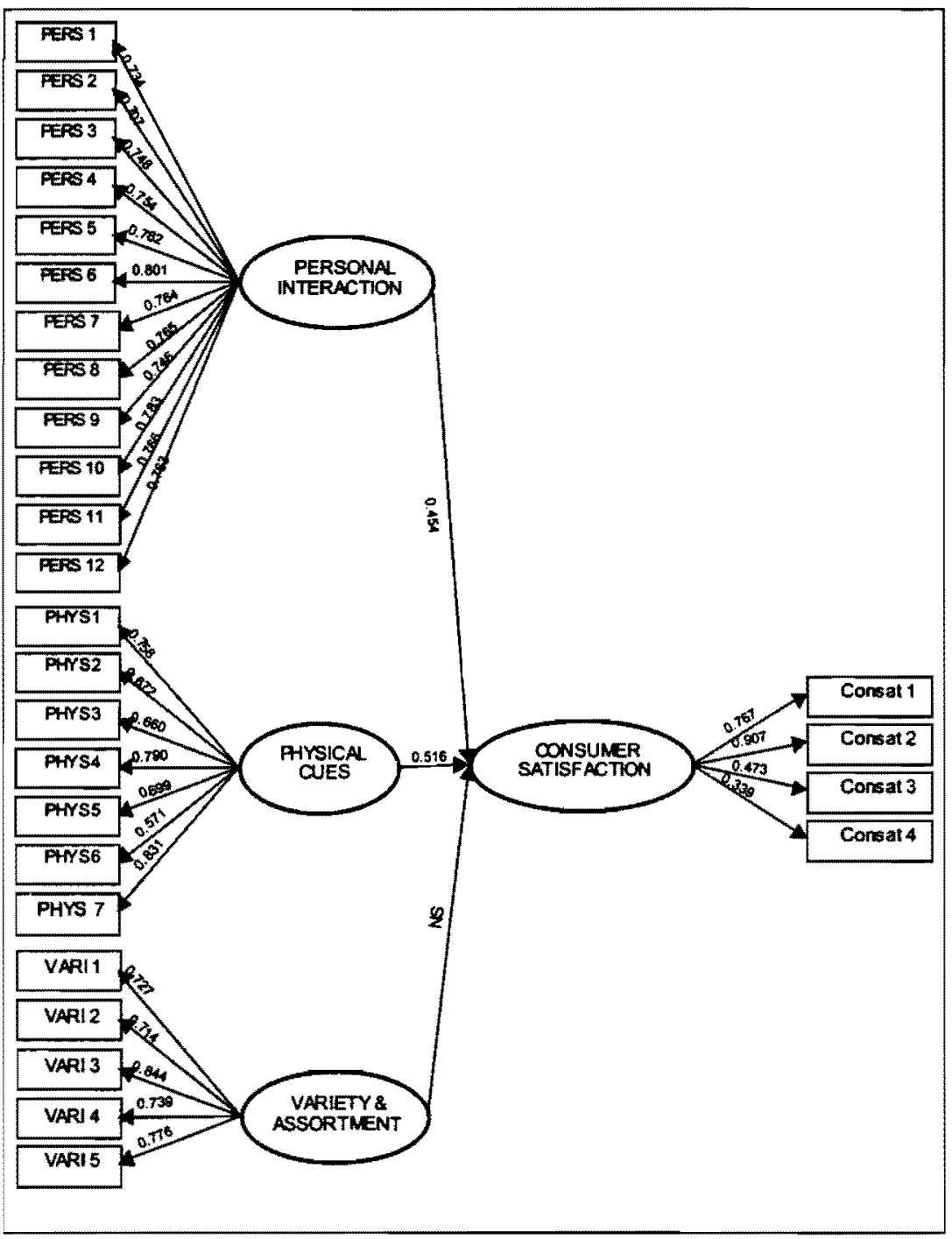

In the fast food and supermarket sub-samples a similar pattern emerged - the same two dimensions being significant and variety and assortment being nonsignificant. The only difference is that in the fast food sub-sample, personal interaction is a stronger predictor of consumer satisfaction than physical cues, while the opposite is true for the supermarket sub-sample. Thus, the pattern of 
associations is the same in all three models and Proposition 2 is therefore accepted. It must be recognised, however, that the magnitudes of the path coefficients differ and that the relative importance of the dimensions influencing consumer satisfaction also differs.

The empirical results summarised in figures 3 and 4 show considerable variability in the path coefficients between the fast food sample/model and the supermarket sample/model. In the case of personal interaction for fast foods, the coefficient is 0.634 compared to 0.454 for supermarkets, and for physical cues it is 0.349 and 0.516 respectively. For variety and assortment, the coefficients are almost identical. It is apparent that in the more service-orientated fast food industry/sector, personal interaction have a considerable stronger impact on CONSAT than in a supermarket environment where products and physical cues appear more dominant.

Although the variety and assortment of merchandise did not emerge as a variable that directly influences customer satisfaction, it should be noted that perceptions of variety and assortment are correlated with both the personal interaction dimension and the physical cues dimension. In other words, by enhancing perceptions of variety and assortment a retailer can indirectly improve customer satisfaction.

\section{6}

MANAGERIAL IMPLICATIONS

In the fast food sub-sample, personal interaction is a stronger predictor of customer satisfaction than physical cues. These results thus suggest that a fast food retailer or store manager wishing to enhance the total retailing experience of its customers, will have to focus its efforts primarily on the interaction between its frontline employees and customers. Employees who are always willing to help, who provide personal, individualised attention, who are courteous when dealing with customers no matter how "difficult" or demanding they may seem to be and who promptly respond to requests, will strongly improve customer satisfaction. In this way, retail firms will not only be able to differentiate themselves but also enhance customer satisfaction, which should in turn increase customer retention and loyalty.

In the supermarket sub-sample, physical cues proved stronger predictors of customer satisfaction than personal interaction. It can thus be deduced that the physical cues which customers encounter are important when they enter a supermarket. Customer perceptions of the quality of merchandise, the physical store environment (floor covering, lighting, and shelves) and even the appearance of supporting physical equipment such as shopping bags and 
catalogues, exert a significant influence on customer satisfaction. It must also be borne in mind that physical cues not only exert a great influence on customer satisfaction, but are also used as inferences on which customers base their purchase decisions.

Notwithstanding the fact that the level of service rendered in a supermarket by way of personal interaction between customers and staff is usually less than that in a fast food retailer, personal interaction also makes a great impact on customer satisfaction. Our results show that in the case of managing a supermarket, the personal interaction between customers and staff also makes a great impact on customer satisfaction, despite the fact that most shopping in supermarkets takes place by means of self-service.

\section{CONCLUSIONS}

The main objective of this study was to compare and assess the stability of an "overall model", based on data collected from four retail sectors, namely clothing, hardware, supermarkets and fast food with two identical models based on only the data from the fast food sub-sample and the supermarket sub-sample. A second objective was to assess whether the three dimensions of the total retail experience modelled in this study as predictors of customer satisfaction, namely personal interaction, physical cues and variety and assortment would impact on customer satisfaction to a similar extent.

In the total sample, personal interaction and physical cues are strong predictors of consumer satisfaction while the variety and assortment dimension does not influence consumer satisfaction. In the fast food and supermarket sub-samples, a similar pattern emerged - the same two dimensions being significant and variety and assortment being non-significant. The only difference is that in the fast food sub-sample, personal interaction is a stronger predictor of consumer satisfaction than physical cues while the opposite is true for the supermarket sub-sample. The pattern of associations is the same in all three models. It must be recognised, however, that the magnitudes of the path coefficients differ and that the relative importance of the dimensions influencing consumer satisfaction also differs. 


\section{REFERENCES}

1 BAKER, J.; GREWAL, D. \& PARASURAMAN, A. (1994) "The Influence of Store Environment on Quality Inferences and Store Image", Journal of the Academy of Marketing Science, 22(4): 328-39.

2 BERMAN, B. \& EVANS, J. R. (1998) Retail Management $\left(7^{\text {th }}\right.$ ed.) Upper Saddle River: Prentice Hall.

3 BERRY, L. L. (1986) "Retail Businesses Are Service Businesses", Journal of Retailing, 62(Spring): 3-6.

4 BERRY, L.L. \& PARASURAMAN, A. (1991) Marketing Services, New York: Free Press.

5 BISHOP, W.R. (1984) "Competitive Intelligence", Progressive Grocer, March: 19-20.

BITNER, M.J. (1990) "Evaluating Service Encounters: The Effects of Physical Surroundings and Employee Responses", Journal of Marketing, 54 (April): 69-82.

7 BLOEMER, J. \& DE RUYTER, K. (1998) "On the Relationship between Store Image, Store Satisfaction and Store Loyalty", European Journal of Marketing, 32(5/6): 499-513.

8 BLOOM, P.H. \& REVE, T. (1990) "Transmitting Signals to Consumers for Competitive Advantage", Business Horizons, 33 (July-August): 58-66.

9 BROWNE, M.W. \& MELS, G. (1992) RAMONA PC Users Guide. Pretoria: Human Sciences Research Council.

10 BUTTLE, F.A. (1995) "What Future for SERVQUAL?", Proceedings of the 24th EMAC Conference, ESSEC, Paris: 211-30.

11 DABHOLKAR, P.A.; THORPE, D.I. \& RENTZ, J.O. (1996) "A Measure of Service Quality for Retail Stores: Scale Development and Validation", Journal of the Academy of Marketing Science, 24(1): 3-16.

12 ARDEN, W.R.; ERDEM, O. \& DARDEN, D.K. (1983) "A Comparison and Test of Three Causal Models of Patronage Intentions", In W.R. Darden \& R.F. Lusch (eds.), Patronage Behavior and Retail Management, New York: North-Holland.

13 DAVIDSON, W.R.; SWEENEY, D.J. \& STAMPFL, R.W. (1988) Retail Management $\left(6^{\text {th }}\right.$ ed. $)$ New York: John Wiley and Sons.

14 DICKSON, J. \& ALBAUM, G. (1977) "A Method for Developing Tailormade Semantic Differentials for Specific Marketing Content Areas", Journal of Marketing Research, 14 (February): 87-91.

15 DICKSON, J,P. \& MACLACHLIN, D.L. (1990) "Social Distance and Shopping Behavior", Journal of the Academy of Marketing Science, 18(2): 153-61.

16 DODDS, W.B.; MONROE, K.B. \& GREWAL, D. (1991) "Effects of Price, Brand, and Store Information on Buyers' Product Evaluations", Journal of Marketing Research, XXVIII (August): 307-19. 
17 DONAVON, R. \& ROSSITER, J.R. (1982) "Store Atmosphere: An Environmental Psychology Approach", Journal of Retailing, 58: 39-52.

18 DOYLE, M. (1984) "New Ways of Measuring Value", Progressive Grocer Value, Executive Report: 15-19.

19 FINN, A. \& KAYANDÉ, U. (1997) "Consistency of the Relationship between Retailer Product and Service Quality", paper presented at the $4^{\text {th }}$ Recent Advances in Retailing and Services Science Conference, Scottsdale, Arizona.

20 FINN, D.W. \& LAMB, C.W. (1991) "An Evaluation of the SERVQUAL Scales in a Retail Setting", In R. Holman and M.R. Solomon (eds.) Advances in Consumer Research, Provo, UT: Association for Consumer Research.

21 GASKI, J.F. \& ETZEL, M.J (1986) "The Index of Consumer Sentiment toward Marketing", Joumal of Marketing, 50 (July): 71-81.

22 GERBNGG, D.W. \& ANDERSON, J.C. (1988) "An Updated Paradigm for Scale Development Incorporating Unidimensionality and its Assessment", Journal of Marketing Research, 25: 186-92.

23 GHOSH, A. and MCLAFFERTY, S.L. (1987) Location Strategies for Retail and Service Firms. Lexington, MA: Lexington Books.

24 GUTMAN, J. \& ALDEN, S.D. (1985) "Adolescents' Cognitive Structures of Retail Stores and Fashion Consumption: A Means-End Chain Analysis of Quality", In J. Jacoby \& J. Olsen (eds.), Perceived Quality: How Consumers View Stores and Merchandise. Lexington, M.A.: Lexington Books.

25 HAIR, J.F. (JR); ANDERSON, R.E; TATHAM, RL. \& BLACK, W.C. (1998) Multivariate Data Analysis (5 $5^{\text {th }}$ ed.) Upper Saddle River: Prentice Hall.

26 HASTY, R. \& REARDON, J. (1997) Retail Management, New York: McGraw-Hill.

27 HUMMEL, J.W. \& SAVITT, R. (1988) "Integrated Customer Service and Retail Strategy", International Journal of Retailing, 3(2), 5-21.

28 JENNRICH, R.I. \& SAMPSON, P.F. (1966) "Rotation for Simple Loadings", Psychometrika, 31: 313-23.

29 KERIN, R.A.; JAN, A. \& HOWARD, D.J. (1992) "Store Shopping Experience and Consumer Price-Quality-Value Perceptions", Journal of Retailing, 68(4): 376-97.

30 MAZURSKY, D. \& JACOBY, J. (1985) "Forming Impressions of Merchandise and Service Quality", In J. Jacoby and J. Olsen (eds.), Perceived Quality: How Consumers View Stores and Merchandise. Lexington, M.A.: Lexington Books.

31 OLIVER, R. (1981) "Measurement and Evaluation of Satisfaction Processes in Retail Settings", Journal of Retailing, 57 (Fall), 25-48. 
32 PARASURAMAN, A.; BERRY, L.L. \& ZEITHAML, V.A. (1991) "Understanding Customer Expectations of Service", Sloan Management Review, 39 (Spring): 39-48.

33 PARASURAMAN, A., BERRY, L.L. \& ZEITHAML, V.A. (1991) "Refinement and Reassessment of the SERVQUAL Scale", Journal of Retailing, 67(4): 420-50.

34 PARASURAMAN, A.; ZEITHAML, V.A. \& BERRY, L.L. (1988) "SERVQUAL: A Multiple-Item Scale for Measuring Consumer Perceptions of Service Quality", Journal of Retailing, 64(1): 12-40.

35 PETERSON, R.A. (1994) "A Meta-Analysis of Cronbach's Coefficient Alpha", Journal of Consumer Research: 27: 381-91.

36 RAO, A.R \& MONROE K.B. (1989) "The Effect of Price, Brand Name and Store Name on Buyers' Perceptions of Product Quality: An Integrative Review", Journal of Marketing Research, 26 (August): 351-7.

37 REICHHELD, F.F. (1993) "Loyalty-Based Management", Harvard Business Review: 71(2), 68.

38 RIDGEWAY, N.M.; DAWSON, S.A. \& BLOCH, P.H. (1990) "Pleasure and Arousal in the Marketplace: Interpersonal Differences in ApproachAvoidance Responses", Marketing Letters, 7 (June): 139-47.

39 SCHRIVER, S. (1997) "Customer Loyalty: Going, Going, ........", American Demographics, September: 20-21.

40 SIROHI, N.; MCLAUGHLIN, E.W. \& WITTINK, D.R. (1998) "A Model of Consumer Perceptions and Store Loyalty Intentions for a Supermarket Retailer", Journal of Retailing, 74(2): 223-45.

41 SPEER, T.L. (1996) "They Complain because They Care", American Demographics, May: 13-14.

42 STEIGER, J.H. \& LIND, J.C. (1980) "Statistically Based Tests for the Number of Common Factors", Paper presented at the annual meeting of the Psychometric Society, Iowa.

43 WARD, J.C.; BARNES, J. \& BITNER, J. (1992) "Measuring the Prototypicality and Meaning of Retail Environments", Journal of Retailing, 68 (Summer): 194-220.

44 WESTBROOK, R.A. (1981) "Sources of Consumer Satisfaction with Retail Outlets", Journal of Retailing, 57 (Fall): 68-85.

45 ZEITHAML, V. (1988) "Consumer Perceptions of Price, Quality, and Value: A Means-End Model and Synthesis of Evidence", Journal of Marketing, 52(July): 2-22.

46 ZEITHAML, V.A. and BITNER, M.J. (1996) Services Marketing, New York: McGraw-Hill. 